\title{
Agronomic Evaluation of Sorghum Hybrids for Silage Production Cultivated in Semiarid Conditions
}

\author{
Alexandre F. Perazzo ${ }^{1 *}$, Gleidson G. P. Carvalho ${ }^{1}$, Edson M. Santos ${ }^{2}$, Higor F. C. Bezerra ${ }^{2}$, \\ Thiago C. Silva ${ }^{3}$, Gildenia A. Pereira ${ }^{2}$, Rosângela C. S. Ramos ${ }^{4}$ and José A. S. Rodrigues ${ }^{5}$ \\ ${ }^{1}$ Programa de Pós-graduação em Zootecnia, Universidade Federal da Bahia, Salvador, Brazil, ${ }^{2}$ Programa de Pós-graduação \\ em Zootecnia, Universidade Federal da Paraíba, Areia, Brazil, ${ }^{3}$ Departamento de Zootecnia, Universidade Federal da Goiás, \\ Goiânia, Brazil, ${ }^{4}$ Programa de Pós-graduação em Zootecnia, Universidade Estadual do Sudoeste da Bahia, Itapetinga, \\ Brazil, ${ }^{5}$ Centro Nacional de Pesquisa de Milho e Sorgo, Embrapa, Sete Lagoas, Brazil
}

OPEN ACCESS

Edited by:

Marcello Mastrorilli,

Consiglio per la ricerca in agricoltura e l'analisi dell'economia agraria (CREA),

Italy

Reviewed by:

Pasquale Campi,

Consiglio per la ricerca in agricoltura $e$ l'analisi dell'economia agraria (CREA),

Italy

Mary Catherine Christey, New Zealand Institute for Plant \& Food

Research, New Zealand

*Correspondence:

Alexandre F. Perazzo

alexandreperazzo@hotmail.com

Specialty section

This article was submitted to Crop Science and Horticulture,

a section of the journal

Frontiers in Plant Science

Received: 13 February 2017

Accepted: 06 June 2017

Published: 22 June 2017

Citation:

Perazzo AF, Carvalho GGP, Santos EM, Bezerra HFC, Silva TC,

Pereira GA, Ramos RCS and Rodrigues JAS (2017) Agronomic

Evaluation of Sorghum Hybrids for Silage Production Cultivated in Semiarid Conditions.

Front. Plant Sci. 8:1088. doi: 10.3389/fpls.2017.01088
The aim of this study was to study the agronomic traits of different Sorghum bicolor (L.) Moench hybrids for silage productionin semiarid conditions. It was a 1-year evaluation conducted in a randomized block design with 24 treatments and three replicates. The treatments were sorghum hybrids developed by the breeding program of "Embrapa Milho e Sorgo" (Brazilian Agricultural Research Corporation). The fresh matter yield (FMY) in the first cut varied from 22,643.56 to 44,033.15 kg/ha, with an average of 32,607.37 kg/ha, leading to the formation of two groups. Similar results were observed for the dry matter yield (DMY), in which the highest group yielded from 9,471.32 to $14,540.23 \mathrm{~kg} / \mathrm{ha}$ dry matter (DM). For plant regrowth, there was an increase in the number of stems and a decrease in the amount of panicles. Two groups were formed for the accumulated dry matter yield (ADMY), averaging 14,217.91 kg/ha; the highest group showed mean values of $18,003.00$ to $14,221.94 \mathrm{~kg} / \mathrm{ha}$. The evaluated sorghum hybrids exhibited satisfactory accumulated forage yields due to their high yield in regrowth, which indicates that they are suitable for use in animal production systems in semi-arid regions.

Keywords: dry matter, forage, panicle, plant for silage, regrowth

\section{INTRODUCTION}

Sorghum is an important forage crop used in livestock systems in many regions around the world because of its adaptation to different environments (Sanchez et al., 2002; Fonseca et al., 2012; Amelework et al., 2015). In arid and semiarid regions, sorghum is an important source of roughage because of its morpho-physiological adaptations to the water stress that provide high dry matter yield (DMY) and adaptability in areas with uneven distribution of rainfall (Sankarapandian et al., 2013; Ahmeda et al., 2016; Rakshit et al., 2016; Su-jiang et al., 2016).

Beyond those characteristics, sorghum plants have is suitable for silage production (Brocke et al., 2014), because of its high concentration of soluble carbohydrates (Sankarapandian et al., 2013) low buffering capacity and high nutritional value (Lema et al., 2001; Kumar et al., 2015), all of which are essential for adequate lactic acid fermentation (Santos et al., 2013). It is important because silage making is one main method of forage conservation used to provide food for the animals during the drought period in tropical regions.

In this context, the evaluation of sorghum hybrids for silage production is a constant step in the breeding programs because different genotypes are developed over the years, which emphasize the need of their evaluation in different locations and years. According to Qu et al. (2014), 
plant breeders have focused on traits likely to affect its productivity, such as yield and/or forage quality. Thus, to define the average profile of the genetic material of each hybrid, it is necessary to characterize the hybrids through the morphological and productive characteristics, as the percentage participation and the chemical compositions of the major anatomical structures of the plant (Muturi et al., 2014).

One advantage of sorghum is its ability to regrow after the original culture in the field is cut, especially when fertilization is employed (Afzal et al., 2012). Therefore, it is possible to produce silage without the need for replanting sorghum. However, it is important to conduct an agronomic study at each cut due to the possible morphological and physiological changes in the plant that can affect the forage yield and other phenotypic traits, which might consequently modify the nutritional value and fermentation of the silage.

The objective of this study was to perform an agronomic evaluation of 24 sorghum hybrids at the first and second cuts.

\section{MATERIALS AND METHODS}

The experiment was conducted at Estação Experimental Pendência (Experimental Station) of Empresa de Pesquisa Agropecuária da Paraíba S.A.-EMEPA (Agricultural Research Corporation of Paraíba State, Brazil), located in the city of Soledade, Paraiba State, Brazil (coordinates $7^{\circ} 8^{\prime} 18^{\prime \prime} \mathrm{S}$ and $36^{\circ} 27^{\prime} 2^{\prime \prime} \mathrm{W}$; altitude $534 \mathrm{~m}$ ).

Based on the Köppen classification, the climate of the region is a Bsh type (hot semi-arid), with rains from January to April, an average temperature of $\sim 24^{\circ} \mathrm{C}$, a relative humidity of approximately $68 \%$ and an average annual rainfall of $400 \mathrm{~mm}$.

The experimental treatments consisted of 21 sorghum experimental hybrids and three commercial hybrids developed by the breeding program of Embrapa Milho e Sorgo (Brazilian Agricultural Research Corporation). We evaluated the first and second cuts of the following hybrids: 944007, 944056, 944040, 944009, 945015, 945019, 945020, 945023, 945026, 945021, 945027, 945022, 944043, 944033, 944034, 946007, 946015, 946016, 946013, 946042, 946043, BRS655, Volumax and BRS610. The hybrids were evaluated in a randomized-block design with 3 replicates.

Seeds were manually sown in $4.2 \mathrm{~m}^{2}(4.2 \times 1.0 \mathrm{~m})$ plots with $70 \mathrm{~cm}$ between rows. Thinning was performed 30 days after planting to maintain a density of 12 plants per linear meter. The soil was fertilized 15 days after sowing based on the chemical properties of the soil in the experimental area, using $50 \mathrm{~kg}$ nitrogen in the form of ammonium sulfate (Table 1). The crop was grown only under rainfed conditions.

The plants were harvested when the grains reached the milky/dough stage. Two separate harvests were performed for the first cut, because the experimental hybrids reached harvest stage at different days. The length of the cycle of the first cut, from planting to harvest, was 71 and 80 days for the first and second harvests, respectively. At the first harvest, the following hybrids were collected: 944007, 944056, 944040, 944009, 945015, 945019, 945020, 945023, 945026, 945021, 945027, 945022,
944043, 944033, 944034, 946007, 946015, 946016, 946013, 946042, 946043, and BRS655; at the second harvest, only hybrids Volumax and BRS610 were included. Only one harvest was performed at the second cut, and the cycle length for the hybrids from the first cut to regrowth were 40 and 31 days for the first and second harvests, respectively. The evaluation cut was manually performed $10 \mathrm{~cm}$ above the soil surface with knives. For evaluation purposes, we considered the yields of two meters of furrow per plot by counting the number of plants per linear meter. The total accumulated rainfall during the two cycles was $635 \mathrm{~mm}$.

At each cut, we evaluated the plant height $(\mathrm{PH}, \mathrm{m})$, stem diameter (SD, cm), number of tillers (NT), number of leaves $(\mathrm{NL})$, average leaf size (ALS, cm), panicle size (PS, $\mathrm{cm})$, fresh matter yield (FMY, kg/ha) and DMY (kg/ha), and the proportion of the components panicle, leaf blade and stem in the DM of the plant. The NT was determined as the number of tillers per cultivated linear meter and the total meters per hectare. The material collected from each plot was separated into panicles, leaf blades and stems, and each fraction was separately weighed. To estimate the DM content, a subsample of each fraction was dried at $65^{\circ} \mathrm{C}$ until a constant weight was reached. From these data, we assessed the proportion of plant components in $\mathrm{g} / \mathrm{kg}$ for DM. Fresh matter yield, expressed as $\mathrm{kg} / \mathrm{ha}$, was calculated as the product between the yield of a cultivated linear meter and the total cultivated linear meters per hectare. Dry matter yield, expressed as $\mathrm{kg} / \mathrm{ha}$, was estimated as the product between the FMY and the DM content. The total fresh matter yield (TFMY) was estimated as the sum of the FMY obtained from the 2 cuts, and the total dry matter yield (TDMY) was estimated as the sum of the DMY obtained from the 2 cuts.

The results were subjected to variance analysis considering the effects of hybrids and blocks, and the Scott-Knott test ( $\alpha=$ 0.05 )was used to compare the means of each hybrid within each harvest, by using the SAEG software version 8.0 (Euclydes, 2004).

\section{RESULTS}

The NT was similar among the hybrids at both first and second cuts $(P>0.05)$. Difference $(P<0.05)$ was found for $\mathrm{PH}$ among the hybrids At the first cut, the group with the greatest heights ranged from 1.89 to $2.20 \mathrm{~m}$, whereas the group with the lowest heights ranged from 1.86 to $1.54 \mathrm{~m}$. In the second cut, the average $\mathrm{PH}$ decreased to $1.75 \mathrm{~m}$. The second cut also formed 2 groups, with the taller group varying from 1.98 to $1.73 \mathrm{~m}$ and the shorter group ranging from 1.64 to $1.35 \mathrm{~m}$. Hybrids showed different values of SD $(P<0.05)$ only at the first cut, with the highest values observed for the hybrids $3,4,7,9,10,13,18,23(>2.10 \mathrm{~cm})$.

The number of leaves $(\mathrm{NL})$ in the first cut varied $(P<0.05)$ from 9.83 to 5.33 , with an average of 7.28. Four distinct groups were formed, and hybrids 23 and 24 had the highest values for this variable, at 9.83 and 9.33 , respectively. With regards to the second cut, two groups were formed $(P<0.05)$, with the number of leaves ranging from 8.67 to 6.00 and an average 7.40 (Table 5). The variable average leaf size (ALS), in the first cut, was 57.94, ranging $(P>0.05)$ from 45.17 to $68.33 \mathrm{~cm}$. In the second cut, 
TABLE 1 | The chemical properties of the soil in the experimental area.

\begin{tabular}{|c|c|c|c|c|c|c|c|c|c|c|c|}
\hline $\mathrm{pH}$ & $\mathbf{P}$ & $\mathbf{K}^{+}$ & $\mathrm{Na}$ & $\mathrm{H}^{+}+\mathrm{Al}^{+3}$ & $\mathrm{Al}^{+3}$ & $\mathrm{Ca}^{+2}$ & $\mathrm{Mg}^{+2}$ & SB & CEC & $\mathbf{V}$ & O.M. \\
\hline $\mathrm{H}_{2} \mathrm{O}$ & & & & & & $\mathrm{ol}_{\mathrm{c}} / \mathrm{dm}^{3}$ & & & & $\%$ & $\mathrm{~g} / \mathrm{kg}$ \\
\hline 6.27 & 70.96 & 215.69 & 0.2 & 3.30 & 0,00 & 7.05 & 2.25 & 10.0 & 13.35 & 75.28 & 10.94 \\
\hline
\end{tabular}

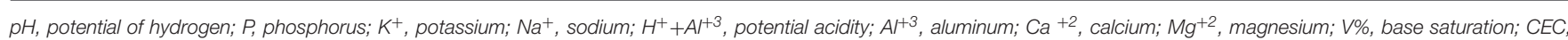
cation exchange capacity; OM, organic matter; SB, Sum of bases.

the average varied $(P>0.05)$ from 41.00 to $56.50 \mathrm{~cm}$, averaging $45.74 \mathrm{~cm}$. A decrease in the ALS was observed for the second cut compared with the first cut. A significant difference $(P<0.05)$ was observed for panicle size (PS) among the hybrids, with the formation of two groups: a higher group, with values ranging from 33.17 to $27.67 \mathrm{~cm}$, and a lower group, with values ranging from 27.00 to $22.33 \mathrm{~cm}$. The hybrids did not differ $(P>0.05)$ in the second cut, but this variable decreased in the second cut $(24.06 \mathrm{~cm})$ compared with the first cut (26.56), which most likely influenced the decrease in the participation of panicles among the components of the sorghum morphology.

The percentage of leaf blades differed $(P<0.05)$ among the hybrids (Table 4) in the first cut. Hybrid 10 was notable, with $322.8 \mathrm{~g} / \mathrm{kg}$ of leaf blades on its tiller, while the average of all genotypes was $138.0 \mathrm{~g} / \mathrm{kg}$. The stem percentages in the first cut was divided into two groups $(P<0.05)$ : one with the highest values $(534.1$ to $694.5 \mathrm{~g} / \mathrm{kg}$, and other with the lowest values $(524.1$ to $322.8 \mathrm{~g} / \mathrm{kg})$. The percentage of panicles in the first cut differed $(P<0.05)$ among the hybrids, with an average of $325.8 \mathrm{~g} / \mathrm{kg}$, to form two groups. The higher group had values ranging from 430.9 to $337.2 \mathrm{~g} / \mathrm{kg}$, whereas the lower group had values ranging from 317.5 to $190.0 \mathrm{~g} / \mathrm{kg}$ of the panicles in the plant.

Hybrids effect was observed $(P<0.05)$ on the percentage of leaf blades among the hybrids in the second cut, and two groups were formed. Hybrids 8 and 23 showed maximum values compared with the other hybrids, with 195.1 and $225.2 \mathrm{~g} / \mathrm{kg}$, respectively. There was no difference among the hybrids $(P>$ 0.05 ) for the stem component in the second cut, and an increase in the amounts of stems for most hybrids was observed in the second cut, with a nearly $7 \%$ increase in the average $(605.6 \mathrm{~g} / \mathrm{kg})$ compared with the first cut. The percentage values of panicles for the second cut did not differ $(P>0.05)$ among the hybrids; however, there was a $7.67 \%$ decrease in the average of this component for the second cut compared with the first, showing that the participation of panicles in the plant was affected by regrowth.

Dry matter content $(P<0.05)$ among the hybrids only for the first cut, with values ranging from 251.0 to $400.1 \mathrm{~g} / \mathrm{kg}$ (Table 2). Four groups were formed, and the group with the highest DM content (above $370 \mathrm{~g} / \mathrm{kg}$ ) was composed of hybrids 2,4 , and 7. In the second cut, the hybrids showed similar DM content $(P<0.05)$ with an average of $260.7 \mathrm{~g} / \mathrm{kg}$. Fresh matter yield values differed $(P<0.05)$ among the hybrids only in the first cut. Under the conditions of the first cut, the FMY values ranged from 22,643.56 to $44,033.15 \mathrm{~kg} / \mathrm{ha}$ (average $32,607.37 \mathrm{~kg} / \mathrm{ha}$ ), and two groups were formed: a more
TABLE 2 | Mean values of dry matter (DM) content, fresh matter yield (FMY) and dry matter yield (DMY) of 24 sorghum hybrids cultured in the semiarid region.

\begin{tabular}{|c|c|c|c|c|c|c|}
\hline \multirow[t]{2}{*}{ Hybrids } & \multicolumn{2}{|c|}{ DM (g/kg) } & \multicolumn{2}{|c|}{ FMY (kg/ha) } & \multicolumn{2}{|c|}{ DMY (kg/ha) } \\
\hline & Cut 1 & Cut 2 & Cut 1 & Cut 2 & Cut 1 & Cut 2 \\
\hline 944007 & $314.4 c$ & 225.0 & $22,643.56 b$ & $11,384.12$ & $8,182.04 b$ & $2,600.53$ \\
\hline 44056 & $378.0 a$ & 317.8 & $27,803.34 b$ & $15,651.97$ & $10,489.90 a$ & $4,900.15$ \\
\hline 44040 & $251.0 d$ & 258.3 & $33,790.32 a$ & $14,664.13$ & $8,288.41 b$ & $3,827.57$ \\
\hline 944009 & $400.1 \mathrm{a}$ & 262.5 & $35,861.90 a$ & $13,657.11$ & $14,380.17 a$ & $3,594.71$ \\
\hline 45015 & $323.2 b$ & 267.0 & $34,080.44 a$ & $17,689.98$ & $11,006.69 a$ & $4,674.22$ \\
\hline 45019 & $328.9 b$ & 248.7 & $23,355.67 b$ & $12,189.74$ & $10,452.44 b$ & $3,035.75$ \\
\hline 45020 & $395.4 a$ & 268.0 & $34,442.48 a$ & $13,335.82$ & $13,739.19 a$ & $3,570.23$ \\
\hline 45023 & $359.0 \mathrm{~b}$ & 267.2 & $30,414.40 a$ & $14,074.30$ & $11,013.20 a$ & $3,794.80$ \\
\hline 45026 & $294.3 c$ & 269.8 & $25,563.92 b$ & $10,535.35$ & $6,592.17 b$ & $2,860.14$ \\
\hline 45021 & $340.5 b$ & 243.6 & $26,264.04 b$ & $10,439.44$ & $9,077.50 \mathrm{~b}$ & $2,549.35$ \\
\hline 945027 & $272.8 d$ & 252.1 & $30,354.46 a$ & $14,280.50$ & $8,433.98 b$ & $3,570.56$ \\
\hline 945022 & $236.1 d$ & 258.7 & $32,272.59 a$ & $15,076.53$ & $7,624.92 b$ & $3,866.74$ \\
\hline 944043 & $255.2 d$ & 258.7 & $25,880.41 b$ & $14,011.96$ & $8,605.37 \mathrm{~b}$ & $3,647.65$ \\
\hline 944033 & $305.5 \mathrm{c}$ & 273.0 & $39,597.46 a$ & $17,512.56$ & $9,835.30 a$ & $4,790.76$ \\
\hline 944034 & $349.5 b$ & 286.2 & $34,508.42 a$ & $16,308.93$ & $9,471.32 a$ & $4,653.87$ \\
\hline 946007 & $346.8 b$ & 259.3 & $41,254.25 a$ & $12,194.53$ & $14,540.23 a$ & $3,170.26$ \\
\hline 946015 & $332.5 b$ & 257.0 & $33,970.14 a$ & $16,606.24$ & $11,315.50 a$ & $4,265.1$ \\
\hline 946016 & $342.3 b$ & 268.4 & $31,876.98 a$ & $13,805.76$ & 10,913.36a & $3,704.98$ \\
\hline 946013 & $291.1 \mathrm{c}$ & 305.5 & $32,620.25 a$ & $19,871.86$ & $9,552.26 b$ & $5,942.66$ \\
\hline 946042 & $348.4 b$ & 265.3 & $36,588.39 a$ & $17,622.85$ & $12,655.25 a$ & $4,660.75$ \\
\hline 946043 & $300.3 c$ & 260.1 & $38,362.66 a$ & $12,861.08$ & $11,627.44 a$ & $3,342.74$ \\
\hline BRS 655 & $325.2 b$ & 233.5 & $29,903.70 a$ & $16,822.03$ & $9,738.70 \mathrm{~b}$ & $3,963.81$ \\
\hline Volumax & $313.1 \mathrm{c}$ & 229.9 & $36,468.51 a$ & $14,807.99$ & $11,441.15 a$ & $3,379.13$ \\
\hline BRS 610 & $269.4 d$ & 220.6 & $44,033.15 a$ & $15,172.43$ & $11,948.51 a$ & $3,339.84$ \\
\hline Mean & 319.7 & 260.7 & $32,607.37$ & $14,607.38$ & $10,455.21$ & $3,821.10$ \\
\hline$C V$ (\%) & 11.25 & 10.18 & 25.10 & 27.62 & 29.08 & 27.37 \\
\hline
\end{tabular}

Means followed by the same letter in a column do not differ by Scott-Knott test at 5\% probability. ${ }^{*}$ coefficient of variation.

productive group, with FMY values above $30,000.00 \mathrm{~kg} / \mathrm{ha}$, and a less productive group, which averaged from 22,643.56 to $27,803.34 \mathrm{~kg} / \mathrm{ha}$. For the second cut, the average FMY was $14,607.38 \mathrm{~kg} / \mathrm{ha}$, with yields varying between $10,439.44$ and $17,689.98 \mathrm{~kg} / \mathrm{ha}$. According to the average of each cut, the average FMY from the second cut was $43 \%$ of the average FMY from the first cut. Although a few hybrids were more productive in the first cut, they did not maintain their superiority during the regrowth period, as exemplified by hybrids 24 and 16, which 
reached FMY values above $40,000 \mathrm{~kg} / \mathrm{ha}$ in the first cut but produced yields below the average for all hybrids in the second cut.

Effect $(P<0.05)$ of hybrids was observed for the DMY of the first cut, which ranged from $6,592.17$ to $14,540.23 \mathrm{~kg} / \mathrm{ha}$. Two groups were formed: the more productive group, with yields of $9,471.32$ to $14,540.23 \mathrm{~kg} / \mathrm{ha}$, and the less productive group, with yields of $6,592.17$ to $9,077.50 \mathrm{~kg} / \mathrm{h}$. In the second cut, however, the DMY showed no differences $(P>0.05)$ among the hybrids, varying between $2,600.53$ and $5,942.66 \mathrm{~kg} / \mathrm{ha}$, with an average of $3,339.84 \mathrm{~kg} / \mathrm{ha}$.

Table 6 shows the average AFMY and ADMY from the two cuts for the hybrids in question. For the AFMY, the values differed $(P<0.05)$ among the hybrids, forming two groups, with an average of $46,997.21 \mathrm{~kg} / \mathrm{ha}$. The group with the highest productivity had mean values ranging from $57,263.47$ to $47,145.32 \mathrm{~kg} / \mathrm{ha}$, whereas the group with the lowest productivity had an average yield varying from $44,620.57$ to $34,512.01 \mathrm{~kg} / \mathrm{ha}$. The average ADMY also differed $(P<0.05)$ among hybrids, forming two groups. The higher group had mean values ranging from $18,003.00$ to $14,221.94 \mathrm{~kg} / \mathrm{ha}$. For the lower group, the mean values ranged from 13,318.41 to $9,902.43 \mathrm{~kg} / \mathrm{ha}$.

\section{DISCUSSION}

The mean value of all hybrids for the number of tillers (NT) in the first cut $(163,640.75)$ was similar to those found by Botelho et al. (2010), with the exception of hybrid 17, which reached 203,801.67 plants per hectare. In both studies, there was an increase in the number of tillers in the second cut, which can be explained by the lower rate of tiller mortality and increased tillering; tillering was likely stimulated after the first cut, suggesting that all of the plants sprouted, with the emergence of one or more tillers (Table 3). In the current study we obtained a greater number of tillers (NT) than Molina et al. (2000), who evaluated 6 sorghum genotypes and found that genotypes AG2006, CMSXS756, BR601, BRS701, BR303, and BR304 produced 106,00; 98,000; 87,000; 96,000; 105,000; and 99,000 plants per hectare, respectively. Following the recommendations of EMBRAPA Milho e Sorgo, at thinning, considering the row spacing, a stand of 170,000 plants/ha was left. Thus, the difference between the stand at harvest and the stand at thinning can be interpreted as a loss, representing plant mortality, a trait of great importance in the selection and characterization of hybrids.

Silva et al. (2011) evaluated 25 sorghum hybrids in the Paraíban Agreste and verified an average PH of $2.07 \mathrm{~m}$, which was slightly above that observed in the present study. Genotypes Volumax and BRS 610 used in the present study showed lower mean values compared with those from the study conducted by Botelho et al. (2010) under both the first- and second-cut conditions. Monteiro et al. (2004) states that although PH is an important characteristic for forage-sorghum biomass yield, a greater height does not always imply higher DMY, and this relationship is especially dependent on the purposes for which the genotypes have been selected because genotypes with an
TABLE 3 | Mean values for the number of tillers per hectare (NT), plant height $(\mathrm{PH})$, and stem diameter (SD) in the first and second cuts of 24 sorghum hybrids cultured in a semiarid region.

\begin{tabular}{|c|c|c|c|c|c|c|}
\hline \multirow[t]{2}{*}{ Hybrids } & \multicolumn{2}{|c|}{ NT } & \multicolumn{2}{|c|}{ PH } & \multicolumn{2}{|c|}{$S D$} \\
\hline & Cut 1 & Cut 2 & Cut 1 & Cut 2 & Cut 1 & Cut 2 \\
\hline 944007 & $122,281.00$ & $163,041.33$ & $1.86 b$ & $1.76 \mathrm{a}$ & $1.84 b$ & 1.09 \\
\hline 944056 & $167,836.67$ & $189,415.67$ & $1.89 a$ & $1.98 \mathrm{a}$ & $1.67 b$ & 1.39 \\
\hline 944040 & $158,246.00$ & $194,211.00$ & $1.95 \mathrm{a}$ & $1.91 \mathrm{a}$ & $2.21 \mathrm{a}$ & 1.24 \\
\hline 944009 & $165,439.00$ & $184,620.33$ & $2.02 \mathrm{a}$ & $1.98 \mathrm{a}$ & $2.10 a$ & 1.19 \\
\hline 945015 & $175,029.67$ & $203,801.67$ & $1.98 \mathrm{a}$ & $1.82 \mathrm{a}$ & $1.93 b$ & 1.10 \\
\hline 945019 & $172,632.00$ & $155,848.33$ & $1.79 b$ & $1.60 \mathrm{~b}$ & $1.65 b$ & 1.35 \\
\hline 945020 & $155,848.33$ & $187,018.00$ & $1.90 \mathrm{a}$ & $1.64 b$ & $2.15 a$ & 1.23 \\
\hline 945023 & $127,076.33$ & $170,234.33$ & $1.82 \mathrm{~b}$ & $1.35 b$ & $1.87 \mathrm{~b}$ & 1.23 \\
\hline 945026 & $155,848.33$ & $194,211.00$ & $1.54 \mathrm{~b}$ & $1.35 b$ & $2.10 a$ & 1.23 \\
\hline 945021 & $143,860.00$ & $129,474.00$ & $1.77 \mathrm{~b}$ & $1.63 b$ & $2.24 a$ & 1.34 \\
\hline 945027 & $167,836.67$ & $210,994.67$ & $1.57 \mathrm{~b}$ & $1.59 b$ & $1.78 b$ & 1.28 \\
\hline 945022 & $172,632.00$ & $230,176.00$ & $1.60 b$ & $1.54 \mathrm{~b}$ & $1.88 \mathrm{~b}$ & 1.10 \\
\hline 944043 & $158,246.00$ & $191,813.33$ & $2.15 \mathrm{a}$ & $1.86 \mathrm{a}$ & $2.05 a$ & 1.33 \\
\hline 944033 & $189,415.67$ & $194,211.00$ & $1.66 b$ & $1.87 a$ & $1.90 \mathrm{~b}$ & 1.28 \\
\hline 944034 & $158,246.00$ & $175,029.67$ & $2.01 \mathrm{a}$ & $1.88 \mathrm{a}$ & $1.75 b$ & 1.26 \\
\hline 946007 & $189,415.67$ & $172,632.00$ & $1.86 \mathrm{~b}$ & $1.81 \mathrm{a}$ & $1.88 \mathrm{~b}$ & 1.13 \\
\hline 946015 & $203,801.67$ & $196,608.67$ & $2.20 \mathrm{a}$ & $1.94 a$ & $1.88 \mathrm{~b}$ & 1.16 \\
\hline 946016 & $165,439.00$ & $206,199.33$ & $2.12 \mathrm{a}$ & $1.78 \mathrm{a}$ & $2.10 a$ & 1.16 \\
\hline 946013 & $148,655.33$ & $206,199.33$ & $1.95 a$ & $1.90 \mathrm{a}$ & $1.94 b$ & 1.24 \\
\hline 946042 & $177,427.33$ & $191,813.33$ & $2.03 a$ & $1.91 \mathrm{a}$ & $1.64 b$ & 1.35 \\
\hline 946043 & $175,029.67$ & $170,234.33$ & $2.12 \mathrm{a}$ & $1.85 \mathrm{a}$ & $1.65 b$ & 1.24 \\
\hline BRS 655 & $172,632.00$ & 191,813.33 & $1.73 b$ & $1.73 a$ & $1.67 \mathrm{~b}$ & 1.29 \\
\hline Volumax & $110,292.67$ & $134,269.33$ & $2.06 \mathrm{a}$ & $1.59 b$ & $2.35 a$ & 1.35 \\
\hline BRS 610 & $194,211.00$ & $160,643.67$ & $1.82 \mathrm{~b}$ & $1.76 \mathrm{a}$ & $1.95 b$ & 1.30 \\
\hline Mean & $163,640.75$ & $183,521.40$ & 1.89 & 1.75 & 1.92 & 1.24 \\
\hline $\mathrm{CV}^{*}(\%)$ & 22.96 & 20.84 & 14.91 & 9.59 & 13.12 & 11.82 \\
\hline
\end{tabular}

Means followed by the same letter in a column do not differ by Scott-Knott test at 5\% probability. " coefficient of variation.

increased percentage of panicles tend to be shorter. However, for most of the hybrids examined in the present study, the stems were at a higher proportion than panicles (Table 4).

Agronomic traits such as $\mathrm{PH}, \mathrm{SD}$, and NT are variables that can directly affect phytomass yield. The number of tillers is related to the tiller population as a function of the area, whereas $\mathrm{SD}$ and HP are related to the volume and/or weight of the tiller. The associations among these agronomic traits can have important effects, such as influencing stand density, the physical size of the tiller, and biomass production per area, which has been confirmed by Goes et al. (2011), who observed that the highest $\mathrm{PH}$ and SD values provided greater DMY in sorghum.

Flaresso et al. (2000) discussed nutritional value and considered the stems to be responsible for the low nutritional quality of the silage due to the greater presence of fibers in this material. On the other hand, Zanine et al. (2007) emphasized the importance of the stem in the lactic acid fermentation of the silage because this portion of the plant contains the most part of soluble carbohydrates, which are the main substrate for the lactic 
TABLE 4 | Mean values of the leaves, stems and panicles of 24 sorghum hybrids based on dry matter in the first and second cuts in a semiarid region.

\begin{tabular}{|c|c|c|c|c|c|c|}
\hline \multirow[t]{3}{*}{ Hybrids } & \multicolumn{2}{|c|}{ Leaves } & \multirow{2}{*}{\multicolumn{2}{|c|}{$\frac{\text { Stems }}{\ln \mathrm{g} / \mathrm{kg} \text { for } D M}$}} & \multicolumn{2}{|c|}{ Panicles } \\
\hline & & & & & & \\
\hline & Cut 1 & Cut 2 & Cut 1 & Cut 2 & Cut 1 & Cut 2 \\
\hline 944007 & $151.8 \mathrm{~b}$ & $141.6 \mathrm{~b}$ & $455.7 \mathrm{~b}$ & 641.7 & $392.5 \mathrm{a}$ & 216.8 \\
\hline 944056 & $94.9 c$ & $120.6 b$ & $617.5 a$ & 620.2 & $287.6 \mathrm{~b}$ & 259.2 \\
\hline 944040 & $146.6 \mathrm{~b}$ & $141.0 \mathrm{~b}$ & $483.4 \mathrm{~b}$ & 628.2 & $370.0 a$ & 230.7 \\
\hline 944009 & $124.1 \mathrm{c}$ & $134.7 \mathrm{~b}$ & $606.1 \mathrm{a}$ & 636.6 & $269.8 b$ & 228.6 \\
\hline 945015 & $103.5 \mathrm{c}$ & $140.9 b$ & $622.4 a$ & 587.5 & $274.1 \mathrm{~b}$ & 271.6 \\
\hline 945019 & $96.2 \mathrm{c}$ & $147.8 \mathrm{~b}$ & $552.2 \mathrm{a}$ & 522.0 & $351.5 \mathrm{a}$ & 330.3 \\
\hline 945020 & $82.2 \mathrm{c}$ & $165.5 b$ & $501.6 \mathrm{~b}$ & 586.7 & $416.2 a$ & 247.8 \\
\hline 945023 & $115.2 \mathrm{c}$ & $195.1 \mathrm{a}$ & $547.6 a$ & 574.5 & $337.2 \mathrm{a}$ & 230.4 \\
\hline 945026 & $165.8 \mathrm{~b}$ & $139.0 \mathrm{~b}$ & $458.4 \mathrm{~b}$ & 567.0 & $375.7 a$ & 294.0 \\
\hline 945021 & $322.8 \mathrm{a}$ & $160.6 \mathrm{~b}$ & $322.8 \mathrm{~b}$ & 612.1 & $354.3 a$ & 227.3 \\
\hline 945027 & $194.0 \mathrm{~b}$ & $136.1 b$ & $488.5 b$ & 548.4 & $317.5 b$ & 315.6 \\
\hline 945022 & $197.7 \mathrm{~b}$ & $146.0 \mathrm{~b}$ & $414.9 \mathrm{~b}$ & 546.3 & $387.4 a$ & 307.6 \\
\hline 944043 & $147.2 \mathrm{~b}$ & $139.8 b$ & $451.0 \mathrm{~b}$ & 595.9 & $401.8 a$ & 264.4 \\
\hline 944033 & $135.0 \mathrm{~b}$ & $137.3 b$ & $524.1 \mathrm{~b}$ & 619.4 & $340.9 a$ & 243.2 \\
\hline 944034 & $94.1 \mathrm{C}$ & $120.8 b$ & $618.8 \mathrm{a}$ & 559.4 & $287.1 \mathrm{~b}$ & 319.8 \\
\hline 946007 & $124.0 \mathrm{c}$ & $133.9 b$ & $534.1 \mathrm{a}$ & 602.6 & $341.9 a$ & 263.5 \\
\hline 946015 & $155.4 b$ & $139.5 b$ & $504.4 b$ & 692.8 & $340.2 a$ & 167.7 \\
\hline 946016 & $102.7 \mathrm{c}$ & $131.7 \mathrm{~b}$ & $633.6 \mathrm{a}$ & 612.5 & $263.7 \mathrm{~b}$ & 255.8 \\
\hline 946013 & $115.8 \mathrm{c}$ & $125.2 \mathrm{~b}$ & $628.4 a$ & 613.5 & $255.7 \mathrm{~b}$ & 261.3 \\
\hline 946042 & $147.5 b$ & $131.6 b$ & $561.3 a$ & 634.6 & $291.1 \mathrm{~b}$ & 233.8 \\
\hline 946043 & $166.8 b$ & $148.8 b$ & $572.6 a$ & 634.3 & $260.6 b$ & 216.9 \\
\hline BRS 655 & $100.1 c$ & $138.6 b$ & $617.7 \mathrm{a}$ & 622.7 & $282.3 b$ & 238.7 \\
\hline Volumax & $112.6 \mathrm{c}$ & $225.2 a$ & $456.5 \mathrm{~b}$ & 602.5 & $430.9 a$ & 172.3 \\
\hline BRS 610 & $115.6 c$ & $144.7 \mathrm{~b}$ & $694.5 \mathrm{a}$ & 673.8 & $190.0 \mathrm{~b}$ & 181.5 \\
\hline Mean & 138.0 & 145.3 & 536.2 & 605.6 & 325.8 & 249.1 \\
\hline $\mathrm{CV}^{*}$ (\%) & 23.97 & 14.82 & 16.91 & 9.52 & 29.22 & 26.06 \\
\hline
\end{tabular}

Means followed by the same letter in column do not differ by Scott-Knott test at 5\% probability. ${ }^{*}$ coefficient of variation.

acid bacteria, which is responsible for the proper preservation of the silage (Table 5).

Comparing plant components, Neumann et al. (2002) concluded that the panicle is the sorghum plant component that can determine silage quality because it has the highest concentrations of DM, crude protein $(\mathrm{CP})$ and in vitro dry matter digestibility (IVDMD), as well as the lowest levels of fibrous components, compared with the stems and leaves. However, for an effective use of sorghum grain, it is necessary that the panicles be disintegrated or at least broken in the process of forage grinding. According to Silva et al. (2011), greater participation of panicles in sorghum may result in an increased nutritional value for the silage, due to the increased amount of total digestible nutrients.

During the regrowth of sorghum, there was an increased percentage of stems and a decreased percentage of panicle; we can thus assume that there was a possible decrease in the nutritional value of the plant because the panicle is the most nutritious part
TABLE 5 | Mean values of the number of leaves (NL), the average leaf size (ALS) and the panicle size (PS) in the first and second cuts of 24 sorghum hybrids cultured in a semiarid region.

\begin{tabular}{|c|c|c|c|c|c|c|}
\hline \multirow[t]{2}{*}{ Hybrids } & \multicolumn{2}{|c|}{ NL } & \multicolumn{2}{|c|}{ ALS (cm) } & \multicolumn{2}{|c|}{ PS (cm) } \\
\hline & Cut 1 & Cut 2 & Cut 1 & Cut 2 & Cut 1 & Cut 2 \\
\hline 944007 & $6.17 d$ & $6.50 \mathrm{~b}$ & 59.17 & 42.67 & $25.50 \mathrm{~b}$ & 21.33 \\
\hline 944056 & $6.83 c$ & $7.33 a$ & 51.33 & 46.50 & $23.00 \mathrm{~b}$ & 22.83 \\
\hline 944040 & $8.67 \mathrm{~b}$ & $8.17 a$ & 62.50 & 44.33 & $26.67 b$ & 24.67 \\
\hline 944009 & $7.17 \mathrm{c}$ & $7.67 a$ & 57.67 & 41.00 & $24.17 \mathrm{~b}$ & 22.33 \\
\hline 945015 & $5.50 d$ & $6.67 \mathrm{~b}$ & 68.33 & 50.00 & $29.83 a$ & 27.83 \\
\hline 945019 & $5.33 d$ & $7.67 a$ & 56.67 & 41.00 & $27.67 a$ & 23.50 \\
\hline 945020 & $5.67 d$ & $7.83 a$ & 65.67 & 44.67 & $33.17 a$ & 24.17 \\
\hline 945023 & $6.17 d$ & $7.67 a$ & 57.33 & 42.83 & $27.00 \mathrm{~b}$ & 21.17 \\
\hline 945026 & $6.67 c$ & $7.00 \mathrm{~b}$ & 58.00 & 43.83 & $24.00 \mathrm{~b}$ & 20.17 \\
\hline 945021 & $6.50 c$ & $7.83 a$ & 59.00 & 46.33 & $30.00 \mathrm{a}$ & 25.50 \\
\hline 945027 & $6.67 c$ & $6.00 \mathrm{~b}$ & 60.50 & 48.50 & $26.50 \mathrm{~b}$ & 26.00 \\
\hline 945022 & $7.17 \mathrm{c}$ & $6.67 b$ & 63.17 & 45.50 & $25.00 \mathrm{~b}$ & 21.67 \\
\hline 944043 & $8.17 \mathrm{~b}$ & $8.00 a$ & 65.17 & 46.33 & $29.50 a$ & 24.33 \\
\hline 944033 & $7.33 c$ & $6.67 \mathrm{~b}$ & 54.33 & 48.33 & $22.33 b$ & 25.50 \\
\hline 944034 & $7.67 \mathrm{~b}$ & $7.00 \mathrm{~b}$ & 57.50 & 46.83 & $25.00 \mathrm{~b}$ & 24.17 \\
\hline 946007 & $7.33 c$ & $7.00 \mathrm{~b}$ & 60.50 & 41.50 & $25.00 \mathrm{~b}$ & 25.00 \\
\hline 946015 & $8.00 \mathrm{~b}$ & $7.50 a$ & 63.33 & 44.67 & $30.17 a$ & 25.00 \\
\hline 946016 & $7.00 \mathrm{c}$ & $8.00 a$ & 54.83 & 44.50 & $29.50 a$ & 22.83 \\
\hline 946013 & $8.50 \mathrm{~b}$ & $7.33 a$ & 45.17 & 45.17 & $24.00 \mathrm{~b}$ & 24.83 \\
\hline 946042 & $8.50 \mathrm{~b}$ & $7.50 a$ & 51.67 & 46.33 & $26.33 b$ & 26.17 \\
\hline 946043 & $8.50 \mathrm{~b}$ & $8.50 a$ & 58.33 & 44.67 & $26.17 \mathrm{~b}$ & 24.67 \\
\hline BRS 655 & $6.17 d$ & $8.67 a$ & 52.00 & 45.67 & $22.33 b$ & 22.33 \\
\hline Volumax & $9.83 a$ & $7.33 a$ & 56.50 & 56.50 & $28.33 a$ & 23.83 \\
\hline BRS 610 & $9.33 a$ & $7.00 \mathrm{~b}$ & 52.00 & 50.17 & $26.33 b$ & 27.67 \\
\hline Mean & 7.28 & 7.40 & 57.94 & 45.74 & 26.56 & 24.06 \\
\hline CV *(\%) & 11.59 & 9.50 & 12.81 & 8.99 & 13.08 & 9.75 \\
\hline
\end{tabular}

Means followed by the same letter in a column do not differ by Scott-Knott test at 5\% probability. "coefficient of variation.

of the plant, whereas the stem is high in fibers. Additionally, the increased moisture of the sorghum during regrowth can be explained (Table 2) by the stem being the component of highest moisture, while the panicle is responsible for the increase in plant DM for silage. The increased number of stems in the second cut can be explained by the decreases observed in the ALS and PS; thus, the stem component was predominant in the component ratio (Table 4).

According to McDonald et al. (1991), the plant DM content is important in the ensiling process because it is a factor that determines the type of fermentation that will take place within the silo. For the production of good-quality silage, that author suggests that the DM concentration should be greater than 250 $\mathrm{g} / \mathrm{kg}$, which was associated with an appropriate level of soluble carbohydrates. França et al. (2011), by evaluating the qualitative characteristics of sorghum hybrid silage, found variations of 216$287 \mathrm{~g} / \mathrm{kg}$ in the DM content. The average value observed for DM by Colombo et al. (2007) (24.7\%), for sorghum genotypes, are 
TABLE 6 | Mean values for the accumulated fresh matter yield (AFMY) and accumulated dry matter yield (ADMY) of cuts from 24 sorghum hybrids in a semiarid region.

\begin{tabular}{|c|c|c|}
\hline Hybrids & AFMY kg/ha & ADMY kg/ha \\
\hline 944007 & $34,512.01 b$ & $9,902.43 b$ \\
\hline 944056 & 43,042.91b & $15,189.07 a$ \\
\hline 944040 & $49,140.18 a$ & $12,304.21 b$ \\
\hline 944009 & $49,073.04 a$ & 18,003.00a \\
\hline 945015 & $51,084.68 a$ & $15,345.64 a$ \\
\hline 945019 & $35,516.63 b$ & $10,889.58 b$ \\
\hline 945020 & $48,521.58 a$ & $17,302.56 a$ \\
\hline 945023 & 43,328.23b & $14,703.51 a$ \\
\hline 945026 & $36,223.94 b$ & $10,116.12 b$ \\
\hline 945021 & $39,259.39 b$ & $12,235.19 b$ \\
\hline 945027 & $43,134.02 b$ & $11,736.77 b$ \\
\hline 945022 & $49,483.04 a$ & $12,102.31 b$ \\
\hline 944043 & $39,614.25 b$ & $10,165.23 b$ \\
\hline 944033 & $57,263.47 a$ & $17,001.94 a$ \\
\hline 944034 & $50,155.58 a$ & $16,398.76 a$ \\
\hline 946007 & $52,748.66 a$ & $17,476.48 a$ \\
\hline 946015 & $50,024.91 a$ & $15,569.41 \mathrm{a}$ \\
\hline 946016 & $47,145.32 a$ & $14,972.52 a$ \\
\hline 946013 & $51,135.03 a$ & $15,099.31 a$ \\
\hline 946042 & $52,484.92 a$ & $16,852.72 a$ \\
\hline 946043 & $54,849.02 a$ & $15,782.48 a$ \\
\hline BRS 655 & $44,620.57 b$ & $13,318.41 b$ \\
\hline Volumax & $49,732.40 a$ & $14,221.94 a$ \\
\hline BRS 610 & $55,839.26 a$ & $14,540.27 a$ \\
\hline Mean & $46,997.21$ & $14,217.91$ \\
\hline CV (\%) & 18.33 & 20.45 \\
\hline
\end{tabular}

Means followed by the same letter in a column do not differ by Scott-Knott test at 5\% probability. ${ }^{*}$ coefficient of variation.

closer of recommended for silage. These variations in DM are due to climatic factors and forage cutting point.

The results of the current study were confirmed by Botelho et al. (2010), who demonstrated the potential regrowth capacity of sorghum. The sorghum in the present study produced satisfactory yields in the first and second cuts and was thus suitable for silage production. In general, this characteristic is favorable because it reduces production costs by reducing the costs of labor and seeds for sowing, especially by maximizing the use of the area as other crops become viable for both grain and silage, without the need for replanting (Foloni et al., 2008). This aspect is especially interesting for the semi-arid agricultural system because the rural areas of this region are reduced, thus requiring a high yield per unit area.

Evaluating the DMY of 25 sorghum hybrids in the Paraíba Agreste region (Brazil), Silva et al. (2011) observed DMY values ranging from $7,679.87$ to $20,948.70 \mathrm{~kg} / \mathrm{ha}$, with an accumulated rainfall slightly above $400 \mathrm{~mm}$. Perazzo et al. (2013) evaluated sorghum genotypes in place similar to the current study and found DMY values ranging from 10.882 to $14.519 \mathrm{~kg} / \mathrm{ha}$ with rainfall of $115 \mathrm{~mm}$. The values in the second cut for DMY are lower than the 9,000 to $12,000 \mathrm{~kg} /$ ha range found by Botelho et al. (2010) during the regrowth period.

It is important to consider the soil-climate conditions observed during the experimental period. Although the region has a semi-arid climate, abnormal levels of rainfall (total $635 \mathrm{~mm}$ ) occurred during the crop cycle, which caused excessive soil moisture. This high level of water in the soil probably affected the yields, especially of the first cut, during which most of the rain was observed (540-578 mm). Bonfim-Silva et al. (2011) evaluated the initial development of grasses subjected to water stress and showed that sorghum, unlike millet and corn, is tolerant to both flooding and drought conditions. Nevertheless, there was a small drop in shoot dry mass under stress. The high capacity for regrowth observed in sorghum is directly dependent on rainfall. Thus, in microregions with lower precipitation levels, the regrowth yield may be compromised or even become unfeasible due to the end of the rainy season.

According to Rezende et al. (2011), the literature is quite controversial with respect to the data on FMY, given the vast amount of material available in the market and the types of sorghum used (forage, dual purpose or cutting, and grazing), presenting values below and above those obtained in the present study. This type of response varies according to a number of factors such as the fertilization system adopted, the soil type, and the distribution and volume of rainfall. However, besides yield variables, other variables such as plant stand, height, and some morphological characteristics are of great importance, especially in the context of forage conservation for ruminants.

As shown in Table 2, there is a noticeable variation in forage yields among the hybrids and between the cuts; some hybrids have a higher yield in only a single cut. To take advantage of the regrowth of sorghum, a joint evaluation of the cumulative yield of the two cuts is necessary to identify specific genotypes that best exploit the regrowth ability in the forage production system. Botelho et al. (2010), by evaluating the AFMY of the first cut and regrowth, observed accumulations of 88,590.00 and $90,080.00 \mathrm{~kg} / \mathrm{ha}$ for the genotypes Volumax and BRS 610, respectively. In the present study, lower accumulated values of 49,732.40 and 55,839.26, respectively, were observed for these genotypes. Penna et al. (2010) evaluated different cuts of hybrids developed by Embrapa Milho e Sorgo and observed average accumulated values for the two cuts of $21,850.00 \mathrm{~kg} / \mathrm{ha}$ for the first season and $36,570.00 \mathrm{~kg} / \mathrm{ha}$ for the second season, which are lower values than those observed in the current study.

It is worth mentioning that in the present study, the accumulation of forage yields was obtained with a total cycle of 111 days. For semiarid regions, where the rainy season is short (3-4 months), this crop cycle length, including the use of the regrowth, is feasible due to its rapid growth and high productivity, which will therefore reduce production costs and maximize the production system of small farms, as observed by Rao et al. (1999) and Ahmeda et al. (2016). Given the various characteristics presented by the sorghum hybrids, attention should be paid to the forage yields and agronomic characteristics of the plants according to their intended use. These aspects 
influence the type of varieties for use in direct grazing, fresh cut, regrowth, silage production and haymaking.

\section{CONCLUSION}

Overall, the hybrids evaluated in the present study combine high yields with high percentages of panicles in the DM.

The sorghum hybrids showed changes in their agronomic characteristics in the different cuts, with an increased percentage of stems and a decreased percentage of panicles in the regrowth period, resulting in a decrease in the nutritional value of the plants.

\section{REFERENCES}

Afzal, M., Ahmad, A., and Ahmad, A. H. (2012). Effect of nitrogen on growth and yield of sorghum forage (Sorghum bicolor (1.) Moench cv.) Under three cuttings system. Cercetari Agron. Moldova 45, 57-64. doi: 10.2478/v10298-012-0065-y

Ahmeda, I. A. M., Eltiliba, A. M. A., Ganawab, F. H. S., and Islamd, K. R. (2016). Utilization of industrial waste aqueous ammonia for irrigated forage sorghum production. Arch. Agron. Soil. Sci. 62, 93-107. doi: $10.1080 / 03650340.2015 .1039523$

Amelework, B., Shimelis, H., Tongoona, P., Mark Laing, M., and Mengistu, F. (2015). Genetic variation in lowland sorghum (Sorghum bicolor (L.) Moench) landraces assessed by simple sequence repeats. Plant. Genet. Resour. 13, 131-141. doi: 10.1017/S1479262114000744

Bonfim-Silva, E. M., Silva, T. J. A., Cabral, C. E. A., Kroth, B. E., and Rezende, D. (2011). Desenvolvimento inicial de gramíneas submetidas ao estresse hídrico. Rev. Caatinga 24, 180-186.

Botelho, P. R. F., Pires, D. A. A., Sales, E. C. J., Rocha Júnior, V. R., Jayme, D. G., and Reis, S. T. (2010). Avaliação de Genótipos de Sorgo em primeiro corte e rebrota para produção de silagem. Rev. Bras. de Milho e Sorgo 9, 287-297. doi: 10.18512/1980-6477/rbms.v9n3p287-297

Brocke, K. V., Trouche, G.,Weltzien, E., Barro, C. P. K., Sidibé, A., and Zougmoré, R. (2014). Helping farmers adapt to climate and cropping system change through increased access to sorghum genetic resources adapted to prevalent sorghum cropping systems in burkina faso. Exp. Agric. 50, 284-305. doi: $10.1017 /$ S0014479713000616

Colombo, D., Crovetto, G. M., Colombini, S., Galassi, G., and Rapetti, L. (2007). Nutritive value of different hybrids of sorghum forage determined in vitro. Ital. J. Anim. Sci. 6, 289-291. doi: 10.4081/ijas.2007.1s.289

Euclydes, R. F. (2004). Sistema Para Análises Estatísticas e Genéticas- SAEG 8.0, Viçosa: FUNARBE/UFV.

Flaresso, J. A., Gross, C. D., and Almeida, E. X. (2000). Cultivares de milho e sorgo para ensilagem no AltoVale do Itajaí, Santa Catarina. R. Bras. Zootec. 29, 1608-1615. doi: 10.1590/S1516-35982000000600003

Foloni, J. S. S., Tiritan, C. S., Calonego, J. C., and Dundes, L. R., (2008). Rebrota de soqueiras de sorgo em função da altura de corte e da adubação nitrogenada. Ceres 55, 102-108.

Fonseca, L., Mezzalira, J. C., Bremm, C., Filho, R. S. A., Gonda, H. L., and Carvalho, P. C. F. (2012). Management targets for maximising the short-term herbage intake rate of cattle grazing in Sorghum bicolor. Livest. Sci. 145, 205-211. doi: $10.1016 /$ j.livsci.2012.02.003

França, A. F. S., Oliveira, R. P., Miyagi, E. S., Silva, A. G., Peron, H. J. C., and Basto, D. C. (2011). Características fermentativas da silagem de híbridos de sorgo sob doses de nitrogênio. Ci. Anim. Bras. 12, 383-391. doi: 10.5216/cab.v12i3.540

Goes, R. N., Rodrigues, R. A. F., Arf, O., Arruda, O. G., and Vilela, R. G. (2011). Fontes e doses de nitrogênio em cobertura no sorgo granífero na safrinha. Rev. Bras. de Milho e Sorgo 10, 121-129. doi: 10.18512/1980-6477/rbms.v10n2p121-129

Kumar, T. V. A., Samuel, D. V. K., Jha, S. K., and Sinha, J. P. (2015). Twin screw extrusion of sorghum and soya blends: a response surface analysis. J. Agr. Sci. Technol. 17, 649-662.
The sorghum hybrids showed satisfactory accumulations of forage yields due to their high yield after regrowth; therefore, these hybrids are suitable for use in animal production systems in semi-arid regions.

\section{AUTHOR CONTRIBUTIONS}

AP: part of the master's dissertation and responsible for the preparation of the manuscript. GC and ES: teachers responsible for project orientation and statistical analysis. RR, TS, HB, and GP: participated in the data collection of field research. JR: researcher of the Brazilian Corporation of Agricultural Research that provided the seeds and the experimental test.

Lema, M., Felix, A., Salako, S., Cebert, E., and Bishnoi, U. (2001). Nutrient content and in uitro dry matter digestibility of silages made from various grain sorghum cultivars. J. Appl. Anim. Res. 19, 129-136. doi: 10.1080/09712119.2001.9706717

McDonald, P., Henderson, A. R., and Heron, S. (1991). The Biochemistry of Silage. Marlow: Chalcombe.

Molina, L. R., Gonçalves, L. C., Rodriguez, N. M., Rodrigues, J. A. S., Ferreira, J. J., and Ferreira, V. C. P. (2000). Avaliação agronômica de seis híbridos de sorgo (Sorghum bicolor (L.) Moench). Arq. Bras. Med. Vet. Zootec. 52, 385-390. doi: 10.1590/S0102-09352000000400017

Monteiro, M. C. D., Anunciação Filho, C. J., Tabosa, J. N., Oliveira, F. J., Reis, O. V., and Bastos, G. Q. (2004). Avaliação do desempenho de sorgo forrageiro para o semiárido de Pernambuco. Rev. Bras. de Milho e Sorgo 3, 52-61. doi: 10.18512/1980-6477/rbms.v3nlp52-61

Muturi, P. W., Mgonja, M., and Rubaihayo, P. (2014). Identification of new sorghum genotypes resistant to the African and spotted stemborers. Int. J. Trop. Insect Sci. 34, 260-268. doi: 10.1017/S1742758414000459

Neumann, M., Restle, J., Alves Filho, D. C., Bernardes, R. A. C., Arboite, M. Z., and Cerdótes, L. (2002). Avaliação de diferentes híbridos de sorgo (Sorghum bicolor, L. Moench) quanto aos componentes da planta e silagens produzidas. R. Bras. Zootec. 31, 302-312. doi: 10.1590/S1516-35982002000200003

Penna, A. G., Borges, A. L. C. C., Gonçalves, L. C., Rodrigues, J. A. S., Gomes, S. P., and Penna, C. F. A. M. (2010). Produção de seis híbridos de sorgo com capimsudão avaliados em três cortes e em duas épocas de semeadura. Rev. Bras. de Milho e Sorgo 9, 95-107. doi: 10.18512/1980-6477/rbms.v9n1p93-105

Perazzo, A. F., Santos, E. M., Pinho, R. M. A., Campos, F. S., Ramos, J. P. F., and Aquino, M. M. (2013). Características agronômicas e eficiência do uso da chuva em cultivares de sorgo no semiárido. Cienc. Rural 43, 1771-1776. doi: 10.1590/S0103-84782013001000007

Qu, H., Liu, X. B., Dong, C. F., Lu, X. Y., and Shen, Y. X. (2014). Field performance and nutritive value of sweet sorghum in eastern China. Field Crops Res. 157, 84-88. doi: 10.1016/j.fcr.2013.12.010

Rakshit, S., Ganapathy, K. N., Gomashe, S. S., Dhandapani, A., Swapna, M., and Mehtre, S. P. (2016). Analysis of Indian post-rainy sorghum multi-location trial data reveals complexity of genotype $\times$ environment interaction. J. Agric. Sci. 1, 1-16. doi: $10.1017 / \mathrm{S} 0021859616000137$

Rao, D. G., Chopra, R. K., and Sinha, S. K. (1999). Comparative performance of sorghum hybrids and their parents under extreme water stress. J. Agric. Sci. Cambridge 133, 53-59. doi: 10.1017/S0021859699006589

Rezende, G. M., Pires, D. A. A., Botelho, P. R. F., Rocha Junior, B. V. R., Sales, E. C. J., and Jayme, D. G. (2011). Características agronômicas de cinco genótipos de sorgo (Sorghum bicolor (1.) Moench), cultivados no inverno, para a produção de silagem. Rev. Bras. de Milho e Sorgo 10, 171-179. doi: 10.18512/1980-6477/rbms.v10n2p171-179

Sanchez, A. C., Subudhi, P. K., Rosenow, D. T., and Nguyen, H. T. (2002). Mapping QTLs associated with drought resistance in sorghum (Sorghum bicolor L. Moench). Plant Mol. Biol. 48, 713-726. doi: 10.1023/A:1014894130270

Sankarapandian, R., Audilakshmi, S., Sharma, V., Ganesamurthy, K., Talwar, H. S., and Patil, J. V. (2013). Effect of morpho-physiological traits on grain yield of sorghum grown under stress at different growth stages, and stability analysis. J. Agric. Sci. 151, 630-647. doi: 10.1017/S002185961200072X 
Santos, E. M., Silva, T. C., Macedo, C. H. O., and Campos, F. S. (2013). "Lactic acid bacteria in tropical grass silages," in Lactic Acid Bacteria: $R, D$ for Food, Health and Livestock Purposes, ed M. Kongo (Rijeka: InTech), 335-362.

Silva, T. C., Santos, E. M., Azevedo, J. A. G., Edvan, R. L., Perazzo, A. F., and Pinho, R. M. A. (2011). Agronomic divergence of sorghum hybrids for silage yield in the semiarid region of Paraiba. R. Bras. Zootec. 40, 1886-1893. doi: 10.1590/S1516-35982011000900007

Su-jiang, Z., Chaudhry, A. S., Ramdani, D., Osman, A., Xue-feng, G., Edwards, G. R., et al. (2016). Chemical composition and in vitro fermentation characteristics of high sugar forage sorghum as an alternative to forage maize for silage making in Tarim Basin, China. J. Integr. Agric. 15, 175-182. doi: 10.1016/S2095-3119(14)60939-4

Zanine, A. M., Santos, E. M., Ferreira, D. J., and Pereira, O. G. (2007). Populações microbianas e nutricionais nos órgãos do capim-tanzânia antes e após a ensilagem. Semina Ci. Agrárias 28, 143-150. doi: $10.5433 / 1679-0359.2007 \mathrm{v} 28 \mathrm{n} 1 \mathrm{p} 143$
Conflict of Interest Statement: The authors declare that the research was conducted in the absence of any commercial or financial relationships that could be construed as a potential conflict of interest.

The reviewer PC and handling Editor declared their shared affiliation, and the handling Editor states that the process met the standards of a fair and objective review.

Copyright (C) 2017 Perazzo, Carvalho, Santos, Bezerra, Silva, Pereira, Ramos and Rodrigues. This is an open-access article distributed under the terms of the Creative Commons Attribution License (CC BY). The use, distribution or reproduction in other forums is permitted, provided the original author(s) or licensor are credited and that the original publication in this journal is cited, in accordance with accepted academic practice. No use, distribution or reproduction is permitted which does not comply with these terms. 